UDC 342.92

\title{
CONTEMPORARY TREND TO E-ADMINISTRATION AND MODERNIZATION OF UKRAINIAN DRAFT LAW ON ADMINISTRATIVE PROCEDURE
}

\author{
СУЧАСНА ТЕНДЕНЦІЯ ДО ЕЛЕКТРОННОГО АДМІНІСТРУВАННЯ \\ ТА МОДЕРНІЗАЦІЯ УКРАЇНСЬКОГО ЗАКОНОПРОЕКТУ \\ ПРО АДМІНІСТРАТИВНУ ПРОЦЕДУРУ
}

\author{
Shkolyk A.M., Docent at the Department of Administrative and Financial Law \\ Ivan Franko National University of Lviv
}

The paper highlights the current global trend of transformation of classical public administration into e-administration, as well as the influence of this tendency on the legal regulation of administrative procedure. The purpose of the article is to define provisions of general acts on administrative procedure, which are expedient to revise, amend or supplement for the full implementation of the idea of e-administration in administrative legislation and relevant practice.

The study outlines the criteria for assessing the level of the transition of administrative bodies to e-administration, as well as the principles that should be followed when implementing them into administrative practice. Besides, several updated provisions of the Spanish general act on administrative procedures are analyzed which maximize the use of electronic means in public administration.

The overview of the current Ukrainian laws regulating public administration as well the latest version of the draft law on administrative procedure (2020) confirms the existence of the tendency to e-administration in the newest acts of national legislation. At the same time, work on updating of the Ukrainian draft law on administrative procedure shall be continued, taking into consideration modern standards in e-administration. Specific articles in the mentioned draft law that should be supplemented by administrative procedural norms, which will further bring its content closer to modern requirements of e-administration, are named in the study.

The purpose of this update is to increase the efficiency of public administration through the priority implementation of information and communication technologies and to simplify administrative procedures for individuals, primarily in terms of reducing the resources needed and the time spent interacting with administrative bodies. A final version of Ukrainian law (code) "On administrative procedure" will hopefully be more updated in the context and subsequently in less need for further amendments.

Key words: general act on administrative procedure, public administration, information and communication technologies, digitalization, electronic means, improvement of the draft law.

Висвітлено сучасну глобальну тенденцію трансформації класичного публічного адміністрування в електронне адміністрування, а також вплив цієї тенденції на правове регулювання адміністративної процедури. Метою статті є визначення положень загальних актів про адміністративну процедуру, які доцільно переглянути, змінити або доповнити за повноцінної реалізації ідеї електронного адміністрування в адміністративному законодавстві та відповідної практики.

Названо критерії, за якими оцінюється рівень переходу адміністративних органів до електронного адміністрування, а також принципи, якими необхідно керуватися під час його впровадження в адміністративну практику. Проаналізовано ряд оновлених положень іспанського законодавства, спрямованих на максимальне застосування електронних засобів комунікації.

Огляд чинних законів України, що регулюють публічне адміністрування, а також останнього варіанту проєкту Закону «Про адміністративну процедуру» підтверджує наявність тенденції до електронного адміністрування в найновіших актах національного законодавства. Поряд із цим роботу над удосконаленням українського законопроєкту про адміністративну процедуру повинно бути продовжено з урахуванням сучасних стандартів в електронному адмініструванні. У дослідженні названо конкретні статті в українському законопроєкті, які варто доповнити відповідними адміністративно-процедурними нормами, що додатково наблизять його зміст до сучасних вимог електронного адміністрування.

Метою цього оновлення повинні стати як підвищення ефективності публічного адміністрування через пріоритетне впровадження інформаційних і комунікаційних технологій, так і спрощення для приватних осіб адміністративного провадження, передусім у частині зменшення необхідних ресурсів і витраченого часу на взаємодію з адміністративними органами. Остаточна версія українського закону (кодексу) «Про адміністративну процедуру» повинна стати оновленою в цьому контексті та відповідно потребувати меншої кількості подальших доповнень.

Ключові слова: загальний акт про адміністративну процедуру, публічне адміністрування, інформаційні й комунікаційні технології, цифризація, електронні засоби, удосконалення законопроєкту.

A nearly twenty-year history of elaboration and adoption of the Ukrainian general act (initially code, later - law) on administrative procedure has a chance to be finished this year. In May 2020 another version of the draft law "On administrative procedure" was submitted by the Cabinet of Ministers of Ukraine and registered in the Verkhovna Rada of Ukraine [1]. The latest version includes new provisions that reflect global tendency of using contemporary information and communication technologies in public administration. However, these amendments are hardly known to administrative law specialists of our country and shall be analyzed regarding their full compliance with modern trends of e-administration.

In the context of our lawmaking story we have to remind that all former drafts of Ukrainian general act on administrative procedure have been mostly based on German example, Verwaltungsverfahrensgesetz that was adopted in 1976 and significantly influenced corresponding legislation in many European and other jurisdictions. Meanwhile, in the new millennium classic public administration gradually transforms into e-administration (as a constituent element of a much broader concept of e-governance). In new circumstances, legal regulation of public administration and especially legislation on general administrative procedure should not be an obstacle to such a transformation. On the contrary, this legislation should use additional possibilities of information and communication technologies to make public administration more effective and friendly for private persons.

Our research will start with an overall review of current legislation that regulates relations between public administration and private persons in Ukraine, including electronic forms of communication and procedural issues. Lack of general act on administrative procedure in our country does not mean a complete absence of legal regulation of public administration's activities. Current rules and procedures for Ukrainian administrative authorities are mostly scattered across different sector-specific laws and regulations

Though, a few exceptions exist and administrative procedural norms can be found in a few legislative acts of general 
nature. First, the Law of Ukraine "On citizen's appeals" [2] consists of some elements of the administrative procedure (time-limits for administrative decisions, procedural rights of individuals in the relations with public bodies, procedural obligations of public administration). Second, the paragraph 2 of the article 2 of the Code of Administrative Justice [3] foresees ten criteria, by which administrative courts shall examine appealed decisions or actions of administrative authorities. These criteria to a considerable extent correspond to the principles of administrative procedure that are envisaged in the aforementioned draft law. Third, the Law of Ukraine "On administrative services" [4] which introduced regulation of one-stop shops in public administration, also includes some procedural norms and undoubtedly reflects the tendency to e-administration. According to article 9 of this law, administrative services can be provided electronically through the Unified state portal of administrative services, including through the integrated information systems of state and local self-government bodies.

Despite these few exceptions of general nature, special legislation (both laws and by-laws) continues to play a decisive role in the legal support of public administration. Moreover, in some sector-specific legislation, one can find broader use of information and communication technologies in the formulation and implementation of corresponding legal norms. For example, the Tax Code of Ukraine [5] that combines substantial and procedural norms, at the end of 2014 was amended by the article 200-1 that foresees electronic administration of the value-added tax.

Regarding aforementioned transformation of Ukrainian public authorities to e-administration, it is also necessary to note at least two legislative acts: Law of Ukraine "On electronic documents and electronic workflow" [6] and especially Law of Ukraine "On electronic trust services" [7] that substituted previous act on electronic digital signature as well as added some contemporary legislative solutions. In particular, this comparatively new law provided:

- a possibility to use contemporary means of electronic identification, including Mobile ID;

- the digital approach in the fixation of the real-time signing of electronic documents;

- increasing confidentiality and better protection of personal data of electronic users.

In short, the Law of Ukraine "On electronic trust services" might be seen as another step to digitalization, both in interactions between private persons and with public administration. Subsequently, its legal norms of general nature are also used in administrative procedure; more specifically, they allow individuals and public officials to communicate by electronic means.

This short overview of relevant Ukrainian legislation undoubtedly shows that it is developing but hardly systematically. On one hand, it must be acknowledged that the legislature and the government are trying to introduce modern methods of electronic communication in public administration. On the other hand, lack of general act on administrative procedure objectively causes differences in legal regulation in specific areas of public administration and in using specific instruments. As one of the consequences, the level of transition to electronic administration in certain administrative bodies and certain spheres of administration differs.

Taking into account Ukraine's obligations to adapt its national legislation to acquis communutaire, it is worth showing criteria that are used by the European Union's bodies in the evaluation of e-administration. In particular, the European Commission proposes a five-degree scale in advancing electronic public services:

1. Information on-line. It is possible to search for information on a given public authority and its activities on the authority's website.
2. One-way interaction. It is not only possible to search for information, but also to download official forms from the public authority's website.

3. Two-ways interaction. In addition to searching for information and downloading official forms, it is also possible to return them via the Internet after completing them.

4. Transaction. It is possible to settle the matter via the Internet - obtain information, download and return appropriate forms, along with authentication (identity confirmation), payment of required fees, until receipt of a decision or certificate in an electronic version.

5. Personalization. In addition to the ability to perform all activities for the fourth degree, public services provided by the public authority are organized according to the needs and preferences of specific users [8, p. 774].

In certain areas of Ukrainian public administration, the fourth degree of this scale has been reached. Former State agency on e-governance and nowadays Ministry of digital transformation reports about the gradual increase of public services which can be obtained through the Internet. This process has its failures, for example, some public authorities demand from private persons besides paper versions of documents to complete a procedure. But in any case, the quantity of electronic public services is much higher than a few years ago. Public services that have been added to electronic way, include not only classic administrative services (i.e. registration of business or electronic driver licenses) but also e-services in health and education areas that to a considerable extent are provided in public sector.

Coming back to contemporary standards of e-administration, it is worth mentioning the E-government benchmark report (2018) that was prepared by Dutch and Italian experts for the European Commission [9]. This report foresees a list of principles that will be promoted in the electronic modernization of administration within the European Union. Most of these principles also might and should be used in Ukraine's efforts to transform its public administration to e-administration:

1. Digital by Default. Public administrations should deliver services digitally (including machine-readable information) as the preferred option (while still keeping other channels open for those who are disconnected by choice or necessity). Besides, public services should be delivered through a single contact point or a one-stop-shop and via different channels.

2. Once only principle. Public administrations should ensure that citizens and businesses supply the same information only once to a relevant public body. Public administration offices take action if permitted to internally re-use this data, in due respect of data protection rules, so that no additional burden falls on citizens and businesses.

3. Inclusiveness and accessibility. Public administrations should design digital public services that are inclusive by default and cater to different needs such as those of the elderly and people with disabilities.

4. Openness and transparency. Public administrations should share information and data between themselves and enable citizens and businesses to access control and correct their data; enable users to monitor administrative processes that involve them; engage with and open up to stakeholders (such as businesses, researchers and non-profit organizations) in the design and delivery of services.

5. Trustworthiness and security. All initiatives should go beyond mere compliance with the legal framework on personal data protection and privacy, and information technology security, by integrating those elements in the design phase.

Besides these five principles, another two ones of crossborder and interoperability by default are proposed, but they are designed for the internal relations between administrators within the European Union. So, going back to the mentioned five principles of electronic modernization of administration, our task will be to find out how these principles will influence 
the legal framework of public administration and, in particular, administrative procedure.

First, digital by default principle means that the electronic way of receiving e-services will become the main one. In the context of administrative procedure, it leads to a legal norm that simple administrative proceeding in electronic form will become the principal way of interactions between private persons and public administrations. Exceptions will exist, if necessary, for example, if an individual reasonably insists to be heard before a public authority in person. Or as well in more complicated administrative proceedings, where hearing or even cross-examination is needed.

The principle of "digital by default" was introduced in the latest version of the Ukrainian draft law "On Administrative Procedure". According to its paragraph 2 of the article 66 "written administrative act is issued in electronic form unless otherwise specified" [1].

Second, "once the only" principle is directed to public administration that will be obliged to re-use already given to another authority personal data. It will simplify the initiation of the procedure for an individuals or businesses - a list of necessary information and documents will be shortened. Such a norm might be added to the draft law "On administrative procedure" or to the existing Law of Ukraine "On administrative services".

Third, principles of inclusiveness and accessibility by default are strictly connected with the aforementioned fifth level of personalization of e-services. In the context of administrative procedure, it might be included in legal norms that regulate ways of initiating administrative proceedings and hearings with the participation of senior persons and people with disabilities.

Fourth, the mentioned principles of openness and transparency of public administration are not new ones for general acts on administrative procedure. However, nowadays they are enriched by the possibility of private persons to access control and correct their data. These actions may be done not only in some starting proceedings but also beforehand. Thus, a relevant norm can hardly be seen in the general act on administrative procedure, but definitely in related pieces of legislation

Fifth principles of trustworthiness and security are also directed to public administration, so they are not supposed to be included to procedural legislation that regulates external relations with private persons.

To sum up, most of the abovementioned principles of electronic modernization of administration shall be additionally considered in the future Ukrainian legal framework of public administration. Both substantial and procedural norms should be added in this context to relevant acts of legislation.

Described tendencies and ideas for transforming public administration to e-administration have been differently realized in certain jurisdictions, even within the European Union and not to mention other countries. To our opinion, some legislators are more conservative and not inclined to modify established rules promptly. At the same time, legislation on the administrative procedure (as well as other laws in related areas) has no other choice but to react to a steady trend to e-administration. Relevant legal provisions to varying degrees have been already modified in some jurisdictions of the European Union's member states.

We shall concentrate our analysis on the Spanish example - European country that tried to codify its legislation on administrative procedure already at the end of the nineteenth century. In the mid-twentieth century the first complete codification of Spanish administrative procedure was succeeded, later amended many times and finally, a substantially updated version of the Law "On the Common Administrative Procedure of the Public Administration" was passed in 2015 [10]. In the preamble of the latter law, one can find the assertion that it deepens the streamlining of procedures with the fully electronic operation.
So let us clarify which norms of the current Spanish law reflect the analyzed tendency to e-administration:

1) rules for representation by proxy that can be also made by electronic appearance in the corresponding electronic headquarters;

2) possibility of electronic identification of those interested in the procedure;

3 ) the obligation of public officials to assist in the use of electronic means to the interested parties;

4) additional rights of private person's rights in their relations with public administrations: to electronic communication, to be assisted in the use of electronic means, to obtain and use the means of identification and electronic signature;

5) the obligation of private persons to interact electronically with the public administrations, if it is enshrined in a special law;

6) the obligation of public administration to provide and save electronic documents with regard to completed procedures;

7) the issuance of electronic documents by the public administrations

8) the validity of the electronic copies made by the public administrations;

9) the priority of writing electronic forms of administrative acts and the electronic notification about issued acts.

Partly summarizing, numeral rules of Spanish general law on administrative procedure were reformulated in 2015 , thus implementing digitalization tendency in public administration. It does not mean that all provisions of the previous legislation have been changed - many norms, especially regulating separate stages of the administrative proceeding, for example about hearing, remained unchanged.

In many other European jurisdictions, the level of detail of general acts on the administrative procedure is visibly lower. For example, the Swedish Administrative Procedure Act belongs to so-called framework regulation, consists of only 33 sections and has not been changed significantly (including e-administration issues) since its entry into force more than thirty years ago [11].

It means that different legislative approaches can be successful in countries with different political and legal cultures, but in any case the movement to e-administration is visible in any jurisdiction. The overview of relevant rules in Spanish general law showed us an example of very detailed regulation of electronic means in the general act on administrative procedure itself. As a result, much less procedural issues are regulated in the other related legislative acts, not to mention by-laws.

We dare to affirm that because of post-Soviet administrative traditions, Ukraine also needs more detailed regulation of administrative procedure in the general act, including the analyzed context of digitalization of public administration. As noted earlier, the draft law on administrative procedure of Ukraine was being revised once again. Its final legislative version is naturally unknown yet, so for our study, we shall use the already mentioned last official version [1].

It should be noted that this version of the draft consists much more procedural norms reflecting the analyzed tendency to e-administration. For example, paragraph 6 of the article 32 one can find "revolutionary" norm for Ukrainian legislation: "If the time of receipt of the invitation sent by mail or e-mail is not recorded, it is considered received by the person on the fifth day of sending, unless the invitation was not received or received later" [1] Besides, the following provisions of the draft law on administrative procedure have been amended in line with the trend to e-administration, at least partly:

- registration of an application in an administrative body (paragraph 3 of the article 39);

- rules of evidence in administrative proceeding (paragraph 2 of the article 50 ); 
- forms of an administrative act and securing the electronic form as preferred in administrative proceedings (paragraph 2 of the article 66);

- notification on an issued administrative act (paragraph 4 of the article 72 );

- validation of signatures and copying of documents by administrative bodies (paragraph 4 of the article 100).

However, taking into account previous overview of relevant legal norms in current Spanish general act on administrative procedure, the following provisions of the Ukrainian draft law shall be additionally reconsidered, amended or changed:

- the preamble of the draft that sounds very formally and does not heed modern ideas of good administration and e-administration;

- rights and duties of private persons in the administrative proceeding (article 29);

- representation of private persons (article 30);

- ways of carrying out administrative proceedings (articles 57-59) concerning fixing the priority of simplified proceedings by electronic means.

To sum up, the process of finalizing the Ukrainian draft law on administrative procedure should be consid- ered as an additional opportunity to adopt a truly modern act, which will fully reflects global trend to e-administration. The analysis of the current legislative acts regulating public administration in Ukraine as well the latest version of the draft law on the administrative procedure (2020) confirms the existence of the trend. At the same time, coverage of relevant provisions of the updated version of Spanish general act on administrative procedure demonstrates the feasibility of additional procedural rules which prioritize and maximize the ease of electronic communications between individuals and the public administration. This is especially true for simplified administrative proceedings, which account for over ninety percent in the administrative practice of any country. However, the prioritization of information and communication technologies is also appropriate at the initial and final stages of the administrative procedure in more complex proceedings.

Hopefully, the abovementioned mentioned proposals will allow to improve a final version of Ukrainian law "On Administrative Procedure" and its updated version will be in less need for further amendments.

\section{REFERENCES}

1. Про адміністративну процедуру : Проєкт Закону України № 3745 від 14 травня 2020 p. URL: http://w1.c1.rada.gov.ua/pls/zweb2/ webproc4_1?pf3511=68834.

2. «Про звернення громадян» : Закон України від 2 жовтня 1996 p. URL: https://zakon.rada.gov.ua/laws/show/393/96-\%D0\%B2\%D1\%80.

3. Кодекс адміністративного судочинства України в редакції від 3 жовтня 2017 року URL: https://zakon.rada.gov.ua/laws/show/2747-15.

4. Про адміністративні послуги : Закон України від 6 вересня 2012 p. URL: https://zakon.rada.gov.ua/laws/show/5203-17.

5. Податковий кодекс України в редакції від 29 грудня 2019 р. URL: https://zakon.rada.gov.ua/laws/show/2755-17.

6. Про електронні документи та електронний документообіг : Закон України в редакції від 7 листопада 2018 p. URL: https://zakon.rada.gov.ua/laws/show/851-15.

7. Про електронні довірчі послуги : Закон України від 5 жовтня 2017 р. URL: https://zakon.rada.gov.ua/laws/show/2155-19.

8. Wierzbowski M. Postępowanie administracyjne i sądowoadministracyjne. Warszawa, Wydawnictwo C.H. Beck, 2019.

9. E-government benchmark report (2018). URL: https://ec.europa.eu/information_society/newsroom/image/document/2018-47/egovernment_benchmark_2018_background_report_F21FA84B-0254-F4DB-7B2FC4567D4AA925_55487.pdf.

10. Law 39/2015 of the Kingdom of Spain, on October 1, of the Common Administrative Procedure of the Public Administrations. URL: http://afyonluoglu.org/PublicWebFiles/Reports/PDP/2015\%20Spain-Law\%2039-2015\%20Common\%20Administrative\%20Procedure\%20 of\%20PA.pdf.

11. The 1986 Administrative Procedure Act of the Kingdom of Sweden URL: https://www.kriminalvarden.se/globalassets/om_oss/lagar/forvaltningslagen-engelska.pdf. 